\title{
An Empirical Model for Geopolymer Reactions Involving Fly Ash and GGBS
}

\author{
Beulah M (D), ${ }^{1}$ MR Sudhir $\left(\mathbb{D},{ }^{1}\right.$ Shenen Chen $\mathbb{D D}^{2}$ Sasha Rai, ${ }^{3}$ and Deekshith Jain ${ }^{4}{ }^{4}$ \\ ${ }^{1}$ Department of Civil Engineering, School of Engineering \& Technology, CHRIST (Deemed to be University), Bangalore, \\ Karnataka, India \\ ${ }^{2}$ Civil and Environmental Engineering, University of North Carolina, Charlotte, NC 28223, USA \\ ${ }^{3}$ Department of Civil Engineering, School of Engineering, KS School of Engineering \& Management, Bangalore, Karnataka, India \\ ${ }^{4}$ Department of Construction Technology and Management, Bule Hora University, Blue Hora, Ethiopia
}

Correspondence should be addressed to Deekshith Jain; deekshith.jain@bhu.edu.et

Received 8 October 2021; Revised 6 December 2021; Accepted 27 December 2021; Published 15 January 2022

Academic Editor: Rotana Hay

Copyright (C) 2022 Beulah M et al. This is an open access article distributed under the Creative Commons Attribution License, which permits unrestricted use, distribution, and reproduction in any medium, provided the original work is properly cited.

\begin{abstract}
Numerous works are reported in literature regarding the enhancement of compressive strength of fly ash-GGBS geopolymer combinations with addition of alkali activators of varying concentrations. However, a limited study has been chronicled, revealing the specific role of alkali or alkaline earth contributed by the fly ash-GGBS combinations on the compressive strength development. It is well known that the strength of a geopolymer is dependent on gel formation from $\mathrm{Al} / \mathrm{Si} \mathrm{ratio}, \mathrm{Ca} / \mathrm{Si}$ ratio, and $\mathrm{Ca} /(\mathrm{Si}+\mathrm{Al})$ ratio but their exact role when cured for various extended periods is unknown as yet. In the present study, alkali concentration in a fly ash-GGBS geopolymer combination was varied from $6 \mathrm{M}$ to $12 \mathrm{M}$ with increments of two mol in six different fly ash-GGBS combinations with a minimum of 20 percent and a maximum of 70 percent GGBS. The correlation coefficients between compressive strength and $\mathrm{Al} / \mathrm{Si}, \mathrm{Ca} / \mathrm{Si}$, and $\mathrm{Ca} /(\mathrm{Si}+\mathrm{Al})$ ratios exhibited values higher than 0.95 taken individually. Multiple linear regression analysis with compressive strength (as dependent parameter) and individual values of $\mathrm{Al} / \mathrm{Si}, \mathrm{Ca} / \mathrm{Si}$, and $\mathrm{Ca} /(\mathrm{Si}+\mathrm{Al})$ ratios (as independent parameters) was effectuated. It was observed that, depending on the composition, the compressive strength circumstantiated a changeover from $\mathrm{Ca} / \mathrm{Si}$ to $\mathrm{Ca} /(\mathrm{Si}+\mathrm{Al})$ ratio in the intermediate composition range. Such a detailed analysis is considered supportive of developing a suitable composition which will provide the optimum compressive strength of the combination.
\end{abstract}

\section{Introduction}

In alkali-activated geopolymer systems with calcium-containing solid alumina silicate sources, such as ground granulated blastfurnace slag (GGBS) and calcium fly ash (FA), rapid formation of C-A-S-H gels [1-3] (along with calcium in class C FA) resulting in quick setting $[4,5]$ has been reported. The C-A-S-H gel showed similar features like C-S-H gel presented in conventional OPC (ordinary Portland cement) concrete. Addition of soluble silicates is generally done into the alkaline activating solution for obtaining a rapid sol/gel transition with improved properties. Calcium has been attributed to the early age setting, which increases with time [6-8]. In the Na2O-CaO-SiO2 $\mathrm{Al} 2 \mathrm{O} 3-\mathrm{H} 2 \mathrm{O}$ system, the coprecipitation of geopolymer gel due to Si-Al-H and C-A-S-H has been found to have an exchange reaction where $\mathrm{Na}$ is replaced by $\mathrm{Ca}[9-11]$.

Regarding the role of $\mathrm{Ca}$ on the metakaolin based geopolymers, Chen et al. [10] suggested that the addition of $\mathrm{Ca}$ in metakaolin resulted in faster geopolymer gel formation leading to faster setting time and that there is evidence of $\mathrm{C}-\mathrm{A}-\mathrm{S}-\mathrm{H}$ formation. These conclusions were supported by NMR (nuclear magnetic resonance) studies. Pulgalia and Mondal [11] indicated that in calcia-based systems, the phase characterization becomes difficult because of the coexistence of C-A-S-H, $(\mathrm{C}(\mathrm{N}, \mathrm{K})-\mathrm{A}-\mathrm{S}-\mathrm{H})$, and $(\mathrm{N}, \mathrm{K})-\mathrm{A}-\mathrm{S}-\mathrm{H}$ in the reaction products of fly ash-metakaolin geopolymers containing soluble form of calcium. They further suggested that conventional FTR analysis provided vibrations from initial 
unreacted slag and calcium silicate hydrate and an overlapping pattern which is similar to OPC sample patterns. They resorted to conventional selective acid dissolution technique but also suggested that they could not differentiate between $\mathrm{N}-\mathrm{A}-\mathrm{S}-\mathrm{H}$ and $\mathrm{C}-\mathrm{S}-\mathrm{H}$ gels.

1.1. Geopolymer Paste Modelling in Literature. Previous attempts using numerical modelling to investigate the geochemical reactions in the polymerization of fly ash-GGBS geopolymer combinations included that by Dao et al. (2019) [12], which estimated the compressive strength of geopolymers using numerical methods (neural networks and genetic algorithms) to find an optimum mix design. Dao et al. (2019) [12] also showed that their models have strong potential for predicting the 28-day compressive strength and suggested that the modelling would help in reducing the time and cost of laboratory tests in the optimal design of geopolymer. Yadollahi et al. (2015) [13] estimated the compressive strength of geopolymer concrete using artificial neural networks (ANN) method and found that parameters including silica modulus, $\mathrm{Na}_{2} \mathrm{O}$ content, water/solid ratios, and curing time can affect the compressive and tensile strengths of geopolymer concrete. Naseri et al. (2017) [14] estimated the results of compressive strength of concrete using SVM (Support Vector Machine). Nano-CuO was added at different content levels in self-compacting concrete and $\mathrm{CuO}$ effects were determined. Khotbehsara et al. (2018) [15] estimated the compressive strength of concrete with $\mathrm{SnO}_{2}, \mathrm{ZrO}_{2}$, and $\mathrm{CaCO}_{3}$ nanoparticles. Both SVM (Support Vector Machine) and ANFIS (adaptive neurofuzzy interface system) were used to analyze the results. Badarloo et al. (2018) [16] estimated the relationship between compressive and tensile strengths of concrete using MATLAB software and probabilistic methods, and the error estimated with the experimental data was found to be nil. Awoyera et al. (2020) [17] included mechanistic properties including slump flow and funnel flow in a machine learning model for selfcompacting geopolymer concrete. However, the model had not been tested in full commercial production of geopolymer concrete.

For more mechanistic-based modelling, Zhang et al. (2018) [18] produced theoretical models of geopolymer gels and found them to be close to those produced experimentally using computer simulation through MD (Molecular Dynamics) models with $\mathrm{Si} / \mathrm{Al}$ molar ratios of 2 and 3. The simulation was carried out at temperatures ranging from 650 to $1800 \mathrm{~K}$ and the effect of $\mathrm{Si} / \mathrm{Al}$ ratio and temperature on the polymerization process and the properties of computationally synthesized geopolymer gels were investigated. Cui et al. (2020) [19] compared the flexural behaviors of OPC and geopolymer concretes using Abaqus modelling. Using data obtained from testing and the literature, empirical equations were derived to describe the nonlinear correlation between the compressive strength and elastic modulus of fly ash based geopolymer concrete (CFGPC). They observed that the suggested formula had a reasonably high $R 2$ value of 0.7663 , and when the variations in density were added to the regression analysis, $R 2$ increased to 0.8652 . Ling (2019) [20] observed the role of $\mathrm{SiO}_{2} / \mathrm{Na}_{2} \mathrm{O}$ mole ratio in alkaline solution, alkaline solution concentration in mass percent, and liquid-to-fly ash mass ratio (L/F). Ling observed using artificial neural network (ANN) that the curing temperature and time had significant influences on the setting time, compressive strength, and heat of geopolymerization which are critical properties for a concrete binder. It was concluded that the optimum mix design parameters result in favourable fly ash geopolymer properties (i.e., compressive strength, setting time, and heat generation). By using both Levenberg-Marquardt and Bayesian regularization algorithms, Siva Krishna and Ranga Rao (2019) [21] were able to use ANN models to predict the mechanical properties such as compressive, split tensile, and flexural strength values of concrete and observed that the Levenberg-Marquardt algorithm gave more accurate results than the Bayesian model. Finally, Mehdizadeh et al. (2018) [22] used a statistical experimental design based on response surface methodology (RSM) on an alkali-activated phosphorus slag to predict and optimize the compressive strength of different ages (3, 7 , and 28 days). In their study, the binder samples were prepared with different molar ratios of $\mathrm{SiO} 2 / \mathrm{Na} 2 \mathrm{O}(\mathrm{S} / \mathrm{N})$, $\mathrm{Na} 2 \mathrm{O} / \mathrm{Al} 2 \mathrm{O} 3(\mathrm{Na} / \mathrm{Al})$, and $\mathrm{H} 2 \mathrm{O} / \mathrm{Al} 2 \mathrm{O} 3(\mathrm{H} / \mathrm{Al})$ as alkali activators and the results showed that $\mathrm{S} / \mathrm{N}$ molar ratio had a significant effect on 7 and 28 days of compressive strength. On the other hand, H/Al molar ratio was found to have the most significant effect on compressive strength when compared to other parameters. They concluded that RSM models were statistically adequate and could be used to predict the compressive strength.

1.2. Significance of Research. As per literature, $\mathrm{Al} / \mathrm{Si}$ ratio, $\mathrm{Ca} / \mathrm{Si}$ ratio, and $\mathrm{Ca} /(\mathrm{Si}+\mathrm{Al})$ ratio in combinations may have a critical role to play in the development of compressive strength of the geopolymer system containing calcium and alkaline activators that are responsible for initiating polymeric reactions. Depending on the $\mathrm{CaO} / \mathrm{SiO} 2$ ratio, $\mathrm{Al} 2 \mathrm{O} 3$ / $\mathrm{SiO} 2$ ratio, and $\mathrm{CaO} /(\mathrm{Al} 2 \mathrm{O} 3+\mathrm{SiO} 2)$ ratio, the composition and properties of the gel may change and may affect the overall compressive strength of the product. In this paper, an attempt of using an empirical approach to establish the correlations is reported.

In the current study, the focus is also on the material transition; geopolymers have displayed compressive strengths comparable to the compressive strengths of Portland cements and with additional benefits of high temperature resistance and stability under acid attack. The setting of geopolymers, however, is closely associated with the transition from fluid to solid which can be accelerated with the addition of calcium. Calcium was found to decrease the $\mathrm{Al} / \mathrm{Si}$ ratio for geopolymer formation, in particular the Al-substituted calcium silicate hydrate (C-A-S-H) formation and also the calcium silicate hydrate (C-S-H) formation. When compared to noncalcium mixes which are controlled by $\mathrm{Al} / \mathrm{Si}$ ratios in normal geopolymer gel, calcium mixes experienced faster dissolution with higher compressive strengths. 
It has been suggested that, with calcium addition, the gel substantially accelerated the setting behavior and the formation of $(\mathrm{C}-\mathrm{S}-\mathrm{H})$ and $(\mathrm{C}-\mathrm{A}-\mathrm{S}-\mathrm{H})$ gels has caused the enhanced dissolution of the source material precursors.

In the current study, NMR tests showed that comparable amount of geopolymer gel existed at setting for both calcium and noncalcium mixes, which suggested that the geopolymer gel was partially responsible for the setting process. Since faster geopolymer gel formation was caused by faster dissolution, which yielded more $\mathrm{Al}$ and lowered the $\mathrm{Al} / \mathrm{Si}$ for geopolymer gel formation (as confirmed by quantitative analysis using both 29Si and 27Al NMR spectroscopy), the lower $\mathrm{Al} / \mathrm{Si}$ ratio can be considered to be sufficient to cause the significantly different setting behaviors. Furthermore, calcium consumes $\mathrm{Si}$ in the solution, which has been proven from indirect experiment and simulation.

In synthetic (C-S-H), a low $\mathrm{Ca} / \mathrm{Si}$ ratio leads to high dissolved silica concentrations and low calcium concentrations, while at high $\mathrm{Ca} / \mathrm{Si}$ ratio and in presence of high $\mathrm{pH}$ of 12.5 high calcium and low silica are typically measured. In (C-S-H) with a $\mathrm{Ca} / \mathrm{Si} \geq 1$, the aluminum uptake in $(\mathrm{C}-\mathrm{S}-\mathrm{H})$ depends on the total amount of aluminium present in the sample and a close relation between aqueous aluminium concentrations and the molar $\mathrm{Al} / \mathrm{Si}$ ratio in $\mathrm{C}-\mathrm{A}-\mathrm{S}-\mathrm{H}$ is observed up to an $\mathrm{Al} / \mathrm{Si}$ of approximately $0.1(10,12)$.

It should be noted, however, that the experimental samples prepared are based on synthetic materials that are not as complicated as commercial samples and do not represent the actual conditions of commercial products, and therefore it is logical to conclude that the above-mentioned observations may occur concurrently as the reaction proceeds with prolonged curing period. Furthermore, any change in the strength of the samples is an indirect measurement of the different phase formations and is an approximate representation of the dynamic situation, controlled by $\mathrm{Si}-\mathrm{Al}-\mathrm{Ca}-\mathrm{Na}$ complex association in different stages of reaction, in actual commercial productions. Thus, the dynamic situations prevailing in geopolymer reactions with time cannot be compared with reported static experimental conditions in actuality. However, application and help of both correlation coefficients and multiple linear regression analysis together are definite indicators of the validity of the assumptions and scientific observations made in real-life situations.

The scientific communities have relied on the help of statistical correlations between two observations to establish the direct proof of the dependence/independence of the observations; and, in time-dependent events, multiple linear regression analyses have been the means to establish the correlation between different temporal events. For the current study, a similar approach is used.

1.3. Theory. If a number of samples (A to $G$, Table 1 ) are related to the dependent variable $(\mathrm{Y})$ and independent variables $A, B$, and $C$ (as shown in the table), then the relationship can be expressed as

$$
\mathrm{Y}=\left[\mathrm{K} 1(\mathrm{~A})^{\mathrm{N} 1}\right] \mathrm{x}\left[\mathrm{K} 2(\mathrm{~B})^{\mathrm{N} 2}\right] \mathrm{x}\left[\mathrm{K} 3(\mathrm{C})^{N 3}\right] \text {, }
$$

where Y1 to Y6 are dependent variables (for different sets of experimental data points) related to the independent experimental variable parameters $A$ ( $A 1$ to $A 6), B$ (B1 to B6), and $\mathrm{C}$ ( $\mathrm{C} 1$ to $\mathrm{C} 6)$.

Here, $\mathrm{K} 1, \mathrm{~K} 2$, and $\mathrm{K} 3$ are proportionality constants in the correlation relationship between different $\mathrm{Y}$ and $\mathrm{X}$ values:

$$
\begin{gathered}
\mathrm{Y} \alpha(\mathrm{A})^{\mathrm{N} 1} \text { or } \mathrm{Y}=\mathrm{K} 1(\mathrm{~A})^{\mathrm{N} 1}, \\
\mathrm{Y} \alpha(\mathrm{B})^{\mathrm{N} 2} \text { or } \mathrm{Y}=\mathrm{K} 2(\mathrm{~B})^{\mathrm{N} 2}, \\
\mathrm{Y} \alpha(\mathrm{C})^{\mathrm{N} 3} \text { or } \mathrm{Y}=\mathrm{K} 3(\mathrm{C})^{\mathrm{N} 3} .
\end{gathered}
$$

These may be generalized as

$$
\mathrm{Y}=\left[\mathrm{K} 1(\mathrm{~A})^{\mathrm{N} 1}\right] \mathrm{x}\left[\mathrm{K} 2(\mathrm{~B})^{\mathrm{N} 2}\right] \mathrm{x}\left[\mathrm{K} 3(\mathrm{C})^{\mathrm{N} 3}\right] .
$$

In equation (2), if $N 1=1$, then the equation exhibits a perfect linear relationship. In actual experiments, it is conventional to plot $\operatorname{Ln}(\mathrm{Y})$ versus $\operatorname{Ln}(\mathrm{A})$ values and to observe if the data points follow a linear relationship indicating high correlation between the variables. Similar regression plots between $\mathrm{Ln}(\mathrm{Y})$ (Y1 to Y6) and $\operatorname{Ln}(\mathrm{B})$ (B1 to B6) and $\operatorname{Ln}(C)$ (C1 to $C 6)$ can be made to examine the correlations. A very high correlation coefficient (nearly one) is indicative of an excellent relationship between the dependent and independent variables.

From equations (2)-(5), the following modified expressions can be determined:

$$
\begin{aligned}
& \ln (Y)=\ln (K 1)+\mathrm{N} 1 \ln (A), \\
& \ln (Y)=\ln (K 2)+N 2 \ln (B), \\
& \ln (Y)=\ln (K 3)+N 3 \ln (C) .
\end{aligned}
$$

And

$$
\ln Y=\{\ln (K 1)+N 1 \ln (A)\}+\{\ln (K 2)+N 2 \ln (B)\}+\{\ln (K 3)+N 3 \ln (C)\} .
$$

Or

$$
\ln Y=[\ln ((K 1)+\operatorname{Ln}(K 2)+\operatorname{Ln}(K 3))]+N 1 \ln (A)+N 2 \ln (B)+N 3 \ln (C) .
$$


Or

$$
[\operatorname{Ln} Y-[\operatorname{Ln}(K 1)+\operatorname{Ln}(\mathrm{K} 2)+\operatorname{Ln}(\mathrm{K} 3)]=N 1 \ln (A)+N 2 \ln (B)+N 3 \ln (C)] .
$$

The values of $\operatorname{Ln}(\mathrm{K} 1)$, $\operatorname{Ln}(\mathrm{K} 2)$, and $\operatorname{Ln}(\mathrm{K} 3)$ can be ascertained from the intercepts on the $Y$-axis from individual $\operatorname{Ln}(\mathrm{Y})$ versus $\operatorname{Ln}(\mathrm{A})$ values, $\operatorname{Ln}(\mathrm{Y})$ versus $\operatorname{Ln}(\mathrm{B})$ values, and $\operatorname{Ln}(\mathrm{Y})$ versus $\operatorname{Ln}(\mathrm{C})$ plots.

Equation (9) is modified into multiple linear regression analyses and consists of solving algebraic equations with three unknown parameters. Furthermore, the $\mathrm{Y}$ values are modified as $[\operatorname{Ln}(\mathrm{Y})-[(\operatorname{Ln}(\mathrm{K} 1)+\operatorname{Ln}(\mathrm{K} 2)+\operatorname{Ln}(\mathrm{K} 3)]$ values. The numerical values of different modified Ys (Y1, Y2, Y3, etc.) are equated to the different $\mathrm{A}, \mathrm{B}$, and $\mathrm{C}$ values in the multiple linear regression analysis.

If there are a number of experimental data points $(A, B$, $\mathrm{C}, \mathrm{D}, \mathrm{E}, \mathrm{F}$, and $\mathrm{G})$, then the individual graphs can be made with $\operatorname{Ln}(\mathrm{Y})(\mathrm{Y}=\mathrm{Y} 1 \ldots \mathrm{Y} 6)$ versus $\operatorname{Ln}(\mathrm{A})(\mathrm{A}=\mathrm{A} 1 \ldots \mathrm{A} 6)$ to determine the correlation coefficient values between $Y$ and A. Similar plots can also be made with $\operatorname{Ln}(\mathrm{Y})$ versus $\operatorname{Ln}(\mathrm{B})$ and $\operatorname{Ln}(\mathrm{Y})$ versus $\operatorname{Ln}(\mathrm{C})$. Only correlation coefficients close to one should be included in the relationship equations.

The multiple linear regression analysis, with different combinations (ABC, $\mathrm{ABD}, \mathrm{ABE}, \mathrm{ABF}, \mathrm{ABG}, \mathrm{BCD}, \mathrm{BCE}$, $B C$, etc.) and the N1, N2, and N3 values obtained after solving the different equations, illustrates the influence of these individual parameters $\mathrm{N} 1, \mathrm{~N} 2$, and $\mathrm{N} 3$ on the $\mathrm{Y}$ values. For example, if certain N1 or N2 or N3 values are negative, then they have no effect on Y. Further, a comparison of the numerical values of $\mathrm{N} 1, \mathrm{~N} 2$, and $\mathrm{N} 3$ will highlight the relative influences from each variable on the $\mathrm{Y}$ values.

In the present experimental work, the compressive strength values were taken as dependent parameters $(\mathrm{Y})$, while the molar ratios of $\mathrm{Al} / \mathrm{Si}, \mathrm{Ca} / \mathrm{Si}$, and $\mathrm{Ca} /(\mathrm{Si}+\mathrm{Al})$ were taken as independent parameters (namely, A1, A2, and A3).

It is assumed that the power term associated with each reacting species $(\mathrm{Al} / \mathrm{Si}, \mathrm{Ca} / \mathrm{Si}$, and $\mathrm{Ca} /(\mathrm{Si}+\mathrm{Al}))$ is related to the gel formation and thereby the strength of the samples (indicated in numerical values of power N1, N2, and N3). Also, a numerical value close to 1 is considered as optimum correlation. In actual practice, correlation coefficient calculations among each of the above-mentioned individual combinations with compressive strength should provide values higher than 0.95 .

Determination of the Moles of $\mathrm{Al} / \mathrm{Si}, \mathrm{Ca} / \mathrm{Si}$, and $\mathrm{Ca} /(\mathrm{Si}+\mathrm{Al})$ from the Chemical Compositions. It is pertinent to recognize that silica ( $\mathrm{SiO} 2)$, alumina (Al2O3), and calcia $(\mathrm{CaO})$ mainly participated in the formation of Al-Si gel, Ca-Si gel, and Ca-Si$\mathrm{Al}$ gel, all of which contributed to the compressive strength of the final product.

\section{Materials (Details of the Materials)}

The chemical compositions of fly ash and GGBS slag are given in Table 2.
The XRD pattern and SEM images of the samples are given below (Figures 1-4).

2.1. Alkaline Solution. The alkaline activator was a combination of sodium hydroxide and sodium silicate solutions, where sodium hydroxide solution (of 98\% purity) was used as alkaline activator along with sodium silicate $(\mathrm{SiO} 2=31.0 \%, \mathrm{Na} 2 \mathrm{O}=11.6 \%$, and water $=57.4 \%)$. These sodium hydroxide solutions of required molarity ( $6 \mathrm{M}=240 \mathrm{gm}$ and $12 \mathrm{M}=480 \mathrm{gm}$ ) were separately prepared. Sodium hydroxide solution of the required molarity and the sodium silicate in liquid state were then mixed and stored at room temperature before use.

2.2. Sample Preparation for Experimental Study. Fly ash and GGBS, with $10 \%$ variation by weight in dry condition, were pan-mixed. The mixture varied from $80 \%$ fly ash and $20 \%$ GGBS (F80G20) to 30\% fly ash and 70\% GGBS (F30G70) in six different compositions (A to F). The mixtures were activated by adding alkaline activator solutions $(6 \mathrm{M}$ and $12 \mathrm{M}$ sodium hydroxide separately) and sodium silicate solution and thoroughly mixed.

The external source materials (fly ash and GGBS) were mixed in proportions as described above. Depending on the mix proportion, the alkali activator solution quantities were varied. The minimum addition of solution was for the higher fly ash-based compositions, while the maximum was for the higher GGBS-based compositions. The fresh mixtures of six different compositions (with $6 \mathrm{M}$ sodium hydroxide molarity) and six other different compositions (with $12 \mathrm{M}$ sodium hydroxide molarity) were cast in $50 \mathrm{~mm} \times 50 \mathrm{~mm} \times 50 \mathrm{~mm}$ steel moulds. On completion of 7 days and 28 days of curing, the cubes were tested for compressive strength as per standard testing methods, under exposure to ambient conditions (temperature $25^{\circ} \mathrm{C}$ to $27^{\circ} \mathrm{C}$ and humidity $65 \%$ to $70 \%$ ). The resultant empirical model has been based on the experimental results of approximately 500 test samples.

\section{Results}

Considering the molar quantities of each of the chemicals present in the individual compounds, Table 3 summarizes the details of $\mathrm{Al} / \mathrm{Si}, \mathrm{Ca} / \mathrm{Si}$, and $\mathrm{Ca} /(\mathrm{Si}+\mathrm{Al})$ mole in each individual batch compositions along with the compressive strengths.

The correlation coefficient between experimental compressive strength $(\mathrm{Y})$ and the individual values of $\mathrm{Ln}, \mathrm{Al} / \mathrm{Si}$ ratio, $\mathrm{Ln}, \mathrm{Ca} / \mathrm{Si}$ ratio, and $\mathrm{Ln}, \mathrm{Ca} /(\mathrm{Si}+\mathrm{Al})$ ratio for $6 \mathrm{M}$ and $12 \mathrm{M}$ samples are given in Figures 5-7. 
TABle 1: Dependent and independent variables.

\begin{tabular}{lcccc}
\hline Sample names & Y (dependent variable) & A (independent variable) & B (independent variable) & C (independent variable) \\
\hline A & Y1 & A1 & B1 & C1 \\
B & Y2 & A2 $2 ~$ & B3 & C3 \\
C & Y3 & A3 & B4 & C4 \\
D & Y4 & A4 & B5 & C5 \\
E & Y6 & A5 & B6 & C6 \\
F & Y6 & A6 & \\
\hline
\end{tabular}

Table 2: Chemical analysis of fly ash and GGBS (in weight \%).

\begin{tabular}{lcccccccc}
\hline Material & $\mathrm{SiO} 2$ & $\mathrm{Al} 2 \mathrm{O} 3$ & $\mathrm{CaO}$ & $\mathrm{MgO}$ & $\mathrm{MnO} 2$ & $\mathrm{TiO} 2$ & $\begin{array}{c}\text { Iron } \\
\text { oxide }\end{array}$ & LOI \\
\hline Fly ash & 60.8 & 26.34 & 1.17 & 1.31 & - & - & 4.21 & 1.8 \\
GGBS & 34.79 & 20.07 & 32.78 & 7.23 & - & - & 0.87 & 0.1 \\
\hline
\end{tabular}

3.1. Intercept (K Value) Determination. Table 4 highlights the regression equations of the different experimental samples.

3.2. Multiple Linear Regression Analysis. It is observed that the correlation coefficient values for the different compositions are all nearly one and therefore multiple linear regression analysis was performed with all the different combinations with three different variables N1, N2, and N3 Figures 8-13 display the plots of N1, N2, and N3 with different combinations for 28 days of curing.

Table 5 brings out the trend of silica, alumina, and calcia moles and the ratios of $\mathrm{Al} / \mathrm{Si}, \mathrm{Ca} / \mathrm{Si}$, and $\mathrm{Ca} /(\mathrm{Si}+\mathrm{Al})$ in the four combinations considered.

\section{Analysis and Discussion}

4.1. Analysis of N1 Values Both with Increasing Molarity of Alkaline Solution and with Increasing Compositions from A to $F$. Figures 8 and 9 corroborate N1 (related to Al/Si composition) variations with both increasing molarity and increasing compositions for 28 days of curing. However, with regard to the composition dependence, it is noticed (Figure 9) that the compositions $2(\mathrm{~B}+\mathrm{C}+\mathrm{D})$ and $3(\mathrm{C}+\mathrm{D}+\mathrm{E})$ are critical as there is a fall in N1 values (representing fall in strength). The average chemical compositions were $\mathrm{SiO} 2$ (0.7-0.8 mol), Al2O3 (0.23 mol), and $\mathrm{CaO}(0.27-0.33 \mathrm{~mol})$. It may therefore be reasonable to conclude that a change in mechanism of strength development of the cubes occurred around this composition. This is found to be true for both 7 days' and 28 days' curing periods.

4.2. Analysis of N2 Values Both with Increasing Molarity of Alkaline Solution and with Increasing Compositions from A to $F$. Values of $\mathrm{N} 2$ (related to strength development by $\mathrm{Ca} / \mathrm{Si}$ ratios) exhibited a general negative trend with regard to both the increasing molarity and the increasing compositions. The negative values indicated that they played no role in the strength development process. Here also it is noted that the middle compositions have shown negative values with regard to both the increasing molarity and the increasing combinations of compositions (compositions 2 and 3).
4.3. Analysis of N3 Values Both with Increasing Molarity of Alkaline Solution and with Increasing Compositions from A to F. Figure 12 shows the distribution of $\mathrm{N} 3$ values of $\mathrm{Ca} /(\mathrm{Al}+\mathrm{Si})$ ratio with respect to the strength under increasing molarity of alkaline solution. It is shown that the middle compositions (comp. B and C) demonstrate positive trend with regard to strength for both 7 days' and 28 days' curing. These compositions, in fact, exhibited negative N2 values. It is deduced that the loss in strength in these compositions due to negative $\mathrm{N} 2$ values is compensated by positive $\mathrm{N} 3$ values. Also, compositions 1 and 4 show negative values indicating that $\mathrm{N} 3$ values in these compositions have played no role in strength development. Figure 13 shows the effect of composition on strength at different molarities. It is again observed that the middle compositions showed positive N3 values, while compositions 1 and 4 showed negative values in both low molarity and high molarity and also with increasing curing period. The composition where such strength changeovers in the mechanism have occurred was not unique and was dependent on many other factors such as activity of the reacting source materials which vary depending on their place of origin.

It may be noted that combinations 2 and 3 exhibited wide variations in relationship between compressive strength and N1, N2, and N3 values in the different samples. This could be interpreted as indirect evidence of the formation of transient $\mathrm{Ca}-\mathrm{Si}$ based combinations and/or $\mathrm{Ca}-\mathrm{Al}$ based combinations or some other unknown transient phase formations as reported by Pulgalia and Mondal [11] influencing compressive strength. While combinations 1 and 4 exhibited variations in mean and standard deviations of different experimental parameters (within acceptable 3\%$5 \%$ variations), combinations 2 and 3 represented variations beyond $5 \%$. However, the nature of the qualitative relationships as represented by variations in compositions with variations in compressive strength has suggested that the analytical results can be satisfactorily explained with the help of statistical tools like correlation coefficients and multiple linear regression analysis.

\section{Summary}

The study conducted several experiments to determine the alkali concentration in a fly ash-GGBS geopolymer combination with varied molar concentrations of $6 \mathrm{~mol}$ to $12 \mathrm{~mol}$ with increments of two mol in six different fly ash-GGBS combinations with a minimum of 20 percent and a maximum of 70 percent GGBS. Multiple linear regression analysis with compressive strength (as dependent 


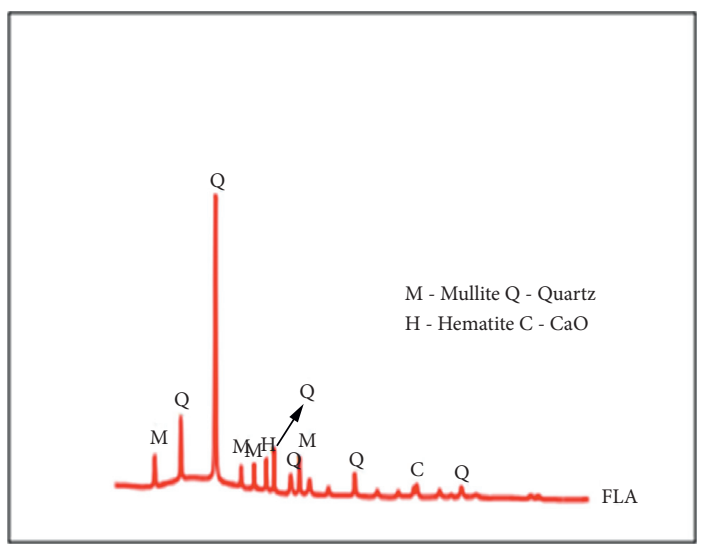

FIGURE 1: XRD pattern of fly ash.

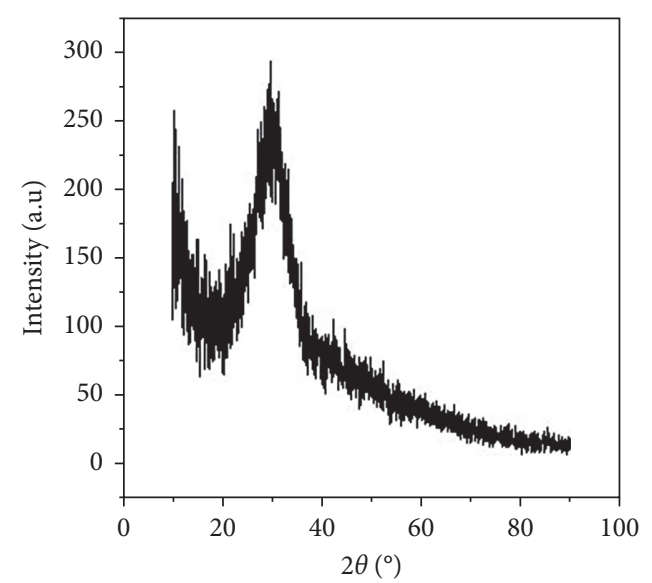

FIGURE 2: XRD pattern of GGBS

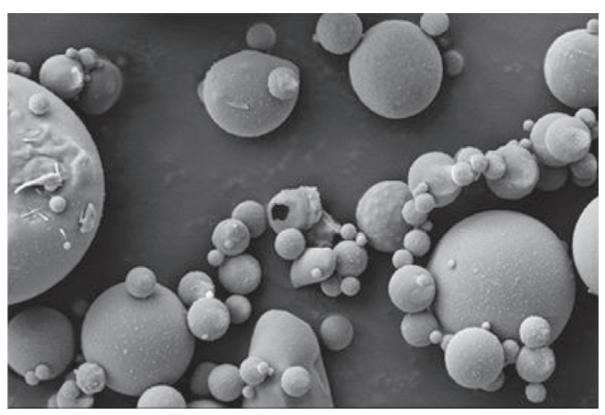

Figure 3: SEM image of fly ash.

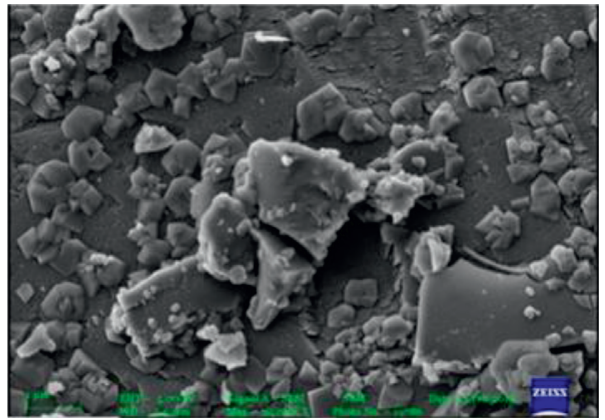

Figure 4: SEM image of GGBS. 


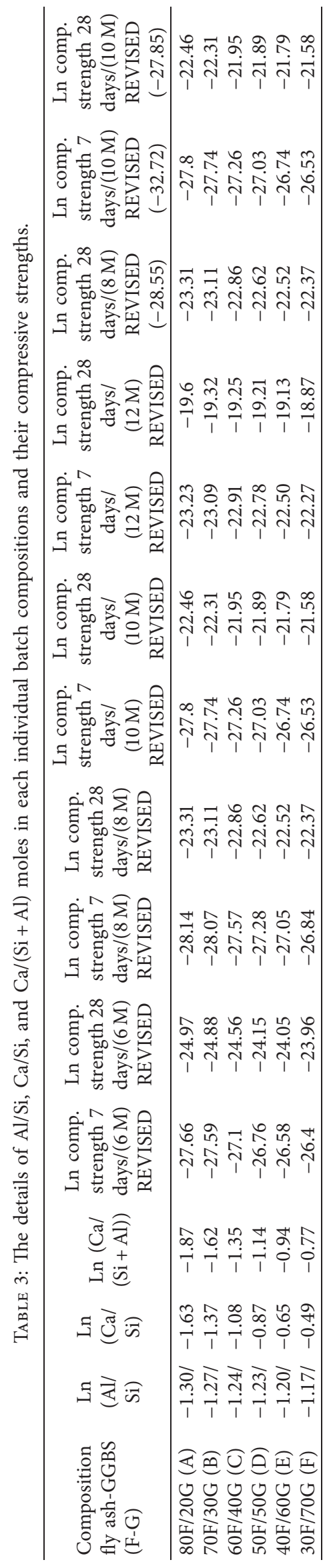




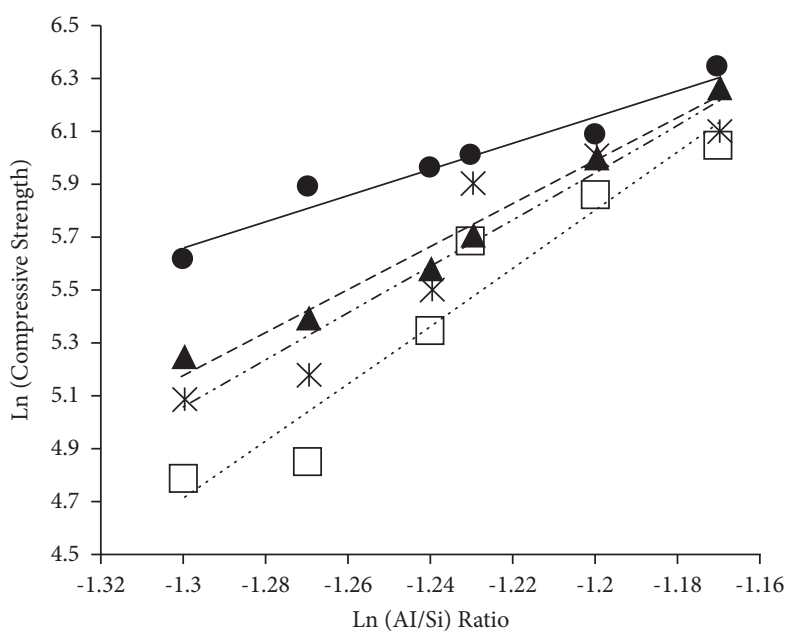

\begin{tabular}{|c|c|}
\hline $\begin{array}{l}\text { Corelation Coefficient: } \\
0.95,6 \mathrm{M}, 7 \text { days }\end{array}$ & $\begin{array}{l}\text { …. Linear (Corelation Coefficient: } \\
0.95,6 \text { M, } 7 \text { days) }\end{array}$ \\
\hline $\begin{array}{l}\text { K Corelation Coefficient: } \\
0.93,6 \mathrm{M}, 28 \text { days }\end{array}$ & $\begin{array}{l}--- \text { Linear (Corelation Coefficient: } \\
\text { 0.93, } 6 \mathrm{M}, 28 \text { days) }\end{array}$ \\
\hline $\begin{array}{l}\text { Corelation Coefficient: } \\
0.97,12 \mathrm{M}, 7 \text { days }\end{array}$ & $\begin{array}{l}\text {-... Linear (Corelation Coefficient: } \\
\text { 0.97, } 12 \text { M, } 7 \text { days) }\end{array}$ \\
\hline $\begin{array}{l}\text { Corelation Coefficient: } \\
0.98,12 \mathrm{M}, 28 \text { days }\end{array}$ & $\begin{array}{l}\text { Linear (Corelation Coefficient: } \\
0.98,12 \mathrm{M}, 28 \text { days) }\end{array}$ \\
\hline
\end{tabular}

Figure 5: Correlation coefficient between experimental compressive strength and $\mathrm{Ln}, \mathrm{Al} / \mathrm{Si}$ ratio for $6 \mathrm{M}$ and $12 \mathrm{M}$ samples.

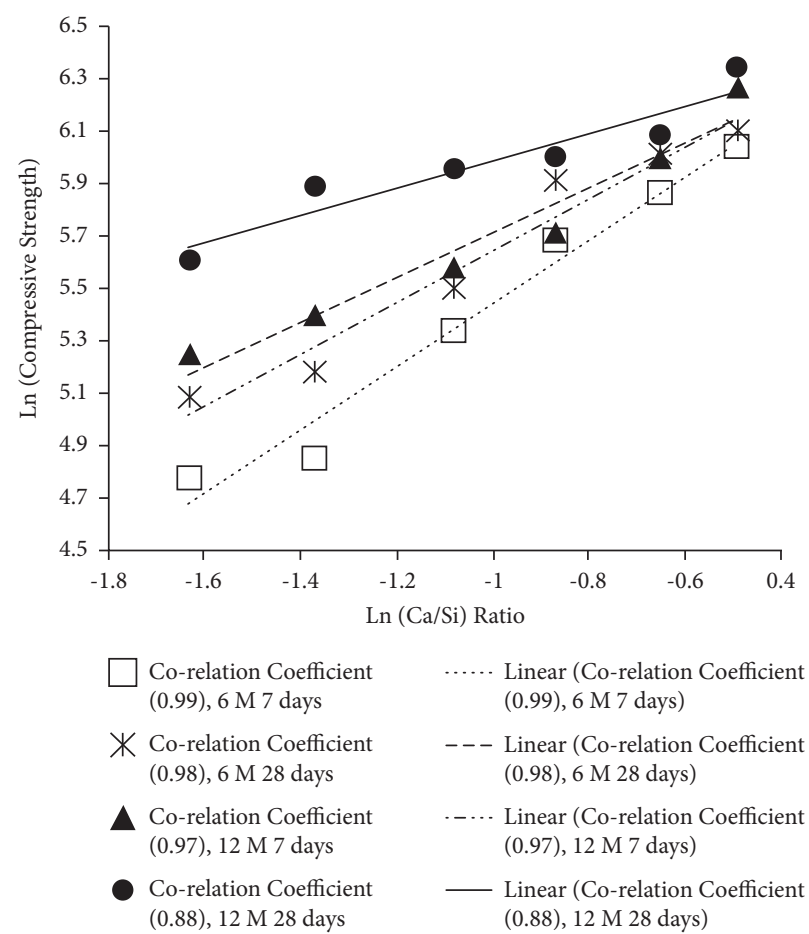

FIgURE 6: Correlation coefficient between experimental compressive strength and $\mathrm{Ln}, \mathrm{Ca} / \mathrm{Si}$ ratio for $6 \mathrm{M}$ and $12 \mathrm{M}$ samples.

parameter) and individual values of $\mathrm{Al} / \mathrm{Si}, \mathrm{Ca} / \mathrm{Si}$, and $\mathrm{Ca} /(\mathrm{Si}+\mathrm{Al})$ )ratios (as independent parameters) was performed. The study demonstrated that the strength of a geopolymer was dependent on gel formation from $\mathrm{Al} / \mathrm{Si}$ ratio, $\mathrm{Ca} / \mathrm{Si}$ ratio, and $\mathrm{Ca} /(\mathrm{Si}+\mathrm{Al})$ ratio and brought out the role played in the setting process during curing.

\section{Prospects, Challenges, Future Work, and Limitations}

The industrial wastes are being produced in large quantities globally with no effective disposal solutions. In this context, the study has attempted to explain the role of fly ash and 


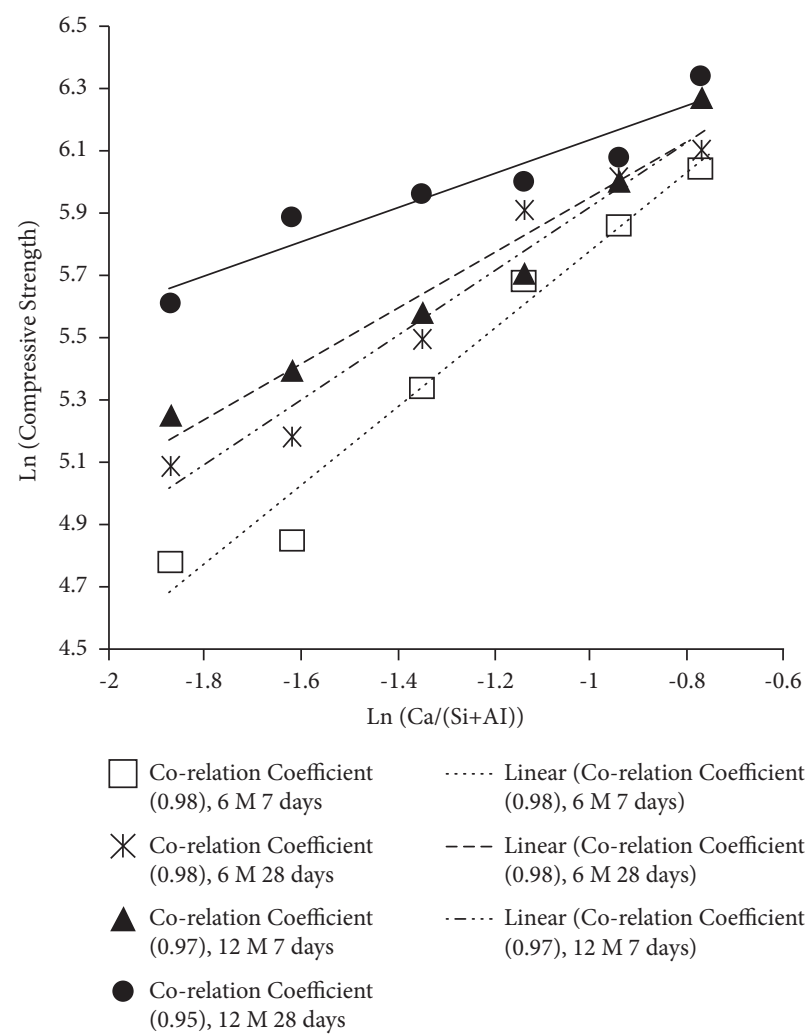

FIgURE 7: Correlation coefficient between experimental compressive strength and $\mathrm{Ln}, \mathrm{Ca} /(\mathrm{Si}+\mathrm{Al})$ ratio for $6 \mathrm{M}$ and $12 \mathrm{M}$ samples.

TABle 4: Determination of $\mathrm{K}$ values from the linear regression equations.

\begin{tabular}{|c|c|c|}
\hline Description of $6 \mathrm{~mol}$ samples & $\begin{array}{c}\text { Linear regression } \\
\text { equation }\end{array}$ & $\begin{array}{l}\text { Numerical value of } \mathrm{K} \text { to be subtracted from experimental } \\
\text { compressive strength values }\end{array}$ \\
\hline $\begin{array}{l}\mathrm{Al} / \mathrm{Si} \text {, corr. coeff. }=0.95(6 \mathrm{M}, 7 \text { days' } \\
\text { strength) }\end{array}$ & $y=18.84+10.86 x$ & \\
\hline $\begin{array}{l}\mathrm{Ca} / \mathrm{Si} \text {, corr. coeff. }=0.99(6 \mathrm{M}, 7 \text { days' } \\
\text { strength })\end{array}$ & $y=6.58+1.10 x$ & $18.84+6.58+7.02=32.44$ \\
\hline $\begin{array}{l}\mathrm{Ca} /(\mathrm{Si}+\mathrm{Al}), \text { corr. coeff. }=0.98(6 \mathrm{M}, 7 \text { days' } \\
\text { strength })\end{array}$ & $y=7.02+1.25 \underline{x}$ & \\
\hline $\begin{array}{l}\mathrm{Al} / \mathrm{Si} \text {, corr. coeff. }=0.93(6 \mathrm{M}, 28 \text { days' } \\
\text { strength })\end{array}$ & $y=16.54+8.83 x$ & \\
\hline $\begin{array}{l}\mathrm{Ca} / \mathrm{Si} \text {, corr. coeff. }=0.98(6 \mathrm{M}, 28 \text { days' } \\
\text { strength })\end{array}$ & $y=6.57+0.90 x$ & $16.54+6.57+6.95=30.06$ \\
\hline $\begin{array}{l}\mathrm{Ca} /(\mathrm{Si}+\mathrm{Al}), \text { corr. coeff. }=0.98(6 \mathrm{M}, \\
28 \text { days' strength })\end{array}$ & $y=6.95+1.03 x$ & \\
\hline $8 \mathrm{~mol} \mathrm{samples}$ & & \\
\hline $\begin{array}{l}\mathrm{Al} / \mathrm{Si} \text {, corr. coeff. }=0.97 \text { ( } 8 \mathrm{M}, 7 \text { days' } \\
\text { strength) }\end{array}$ & $y=19.18+11.11 x$ & \\
\hline $\begin{array}{l}\mathrm{Ca} / \mathrm{Si} \text {, corr. coeff. }=0.97(8 \mathrm{M}, 7 \text { days' } \\
\text { strength })\end{array}$ & $y=6.70+1.22 x$ & $19.18+6,70+7.09=32.97$ \\
\hline $\begin{array}{l}\mathrm{Ca} /(\mathrm{Si}+\mathrm{Al}), \text { corr. coeff. }=0.97(8 \mathrm{M}, 7 \text { days' } \\
\text { strength })\end{array}$ & $y=7.09+1.26 x$ & \\
\hline $\begin{array}{l}\mathrm{Al} / \mathrm{Si} \text {, corr. coeff. }=0.98(8 \mathrm{M}, 28 \text { days' } \\
\text { strength })\end{array}$ & $y=15.10+7.57 x$ & \\
\hline $\begin{array}{l}\mathrm{Ca} / \mathrm{Si} \text {, corr. coeff. }=0.88(8 \mathrm{M}, 28 \text { days' } \\
\text { strength })\end{array}$ & $y=6.59+0.83 x$ & $15.10+6.59+6.86=28.55$ \\
\hline $\begin{array}{l}\mathrm{Ca} /(\mathrm{Si}+\mathrm{Al}) \text {, corr. coeff. }=0.95(8 \mathrm{M}, 28 \\
\text { days' strength }) \\
10 \text { mol samples }\end{array}$ & $y=6.86+0.86 x$ & \\
\hline
\end{tabular}


TABle 4: Continued.

\begin{tabular}{|c|c|c|}
\hline Description of $6 \mathrm{~mol}$ samples & $\begin{array}{l}\text { Linear regression } \\
\text { equation }\end{array}$ & $\begin{array}{l}\text { Numerical value of } \mathrm{K} \text { to be subtracted from experimental } \\
\text { compressive strength values }\end{array}$ \\
\hline $\begin{array}{l}\mathrm{Al} / \mathrm{Si} \text {, corr. coeff. }=0.96 \text { ( } 8 \mathrm{M}, 7 \text { days' } \\
\text { strength) }\end{array}$ & $y=18.88+10.81 x$ & \\
\hline $\begin{array}{l}\mathrm{Ca} / \mathrm{Si} \text {, corr. coeff. }=0.97(8 \mathrm{M}, 7 \text { days' } \\
\text { strength })\end{array}$ & $y=6.73+1.17 x$ & $18.88+6.73+7.11=32.72$ \\
\hline $\begin{array}{l}\mathrm{Ca} /(\mathrm{Si}+\mathrm{Al}), \text { corr. coeff. }=0.95(8 \mathrm{M}, 7 \text { days' } \\
\text { strength })\end{array}$ & $y=7.11+1.22 x$ & \\
\hline $\begin{array}{l}\mathrm{Al} / \mathrm{Si} \text {, corr. coeff. }=0.96(8 \mathrm{M}, 28 \text { days' } \\
\text { strength })\end{array}$ & $y=14.39+6.91 x$ & \\
\hline $\begin{array}{l}\mathrm{Ca} / \mathrm{Si} \text {, corr. coeff. }=0.92(8 \mathrm{M}, 28 \text { days' } \\
\text { strength })\end{array}$ & $y=6.61+0.748 x$ & $14.39+6.61+6.85=27.85$ \\
\hline $\begin{array}{l}\mathrm{Ca} /(\mathrm{Si}+\mathrm{Al}), \text { corr. coeff. }=0.95(8 \mathrm{M}, 28 \\
\text { days' strength })\end{array}$ & $y=6.85+0.78 x$ & \\
\hline 12 mol samples & & \\
\hline $\begin{array}{l}\mathrm{Al} / \mathrm{Si} \text {, corr. coeff. }=0.97(12 \mathrm{M}, 7 \text { days' } \\
\text { strength) }\end{array}$ & $y=15.24+7.73 x$ & \\
\hline $\begin{array}{l}\mathrm{Ca} / \mathrm{Si} \text {, corr. coeff. }=0.97(12 \mathrm{M}, 7 \text { days' } \\
\text { strength) }\end{array}$ & $y=6.46+0.74 x$ & $15.24+6.46+6.79=28.49$ \\
\hline $\begin{array}{l}\mathrm{Ca} /(\mathrm{Si}+\mathrm{Al}), \text { corr. coeff. }=0.97(12 \mathrm{M}, 7 \\
\text { days' strength })\end{array}$ & $y=6.79+0.86 x$ & \\
\hline $\begin{array}{l}\mathrm{Al} / \mathrm{Si} \text {, corr. coeff. }=0.98(12 \mathrm{M}, 28 \text { days' } \\
\text { strength })\end{array}$ & $y=12.10+4.95 x$ & \\
\hline $\begin{array}{l}\mathrm{Ca} / \mathrm{Si} \text {, corr. coeff. }=0.88(12 \mathrm{M}, 28 \text { days' } \\
\text { strength })\end{array}$ & $y=6.44+0.44 x$ & $12.10+6.44+6.67=25.21$ \\
\hline $\begin{array}{l}\mathrm{Ca} /(\mathrm{Si}+\mathrm{Al}) \text {, corr. coeff. }=0.95(12 \mathrm{M}, 28 \\
\text { days' strength })\end{array}$ & $y=6.67+0.55 x$ & \\
\hline
\end{tabular}

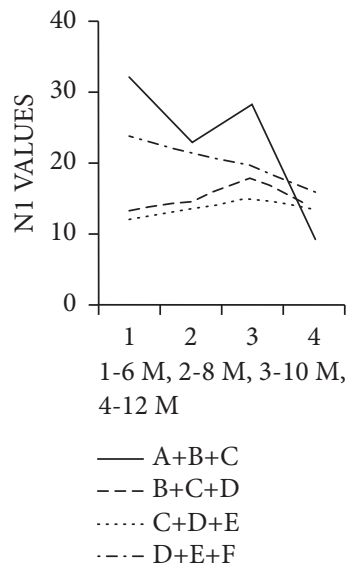

FIGURE 8: N1 values with increasing molarity (28 days' curing) combinations from A to F.

GGBS on compressive strength development by an empirical model. The major challenge for the researchers will be to find ways to increase the usage of these industrial wastes in proportion to their large production. The second challenge will be to accurately establish the individual/collective contributions of the waste constituents in the manufacture of construction materials without comprising on the strength parameters. The scope of research work undertaken was limited to $6 \mathrm{M}$ and $12 \mathrm{M}$. The study can be extended to cover $4 \mathrm{M}, 8 \mathrm{M}$, and $14 \mathrm{M}$ to validate the results of this study over a wider spectrum of research. Also, similar studies can be carried out on other industrial wastes such as metakaolin, silica fumes, slug, rice husk, and various mine wastes with different molarities. 


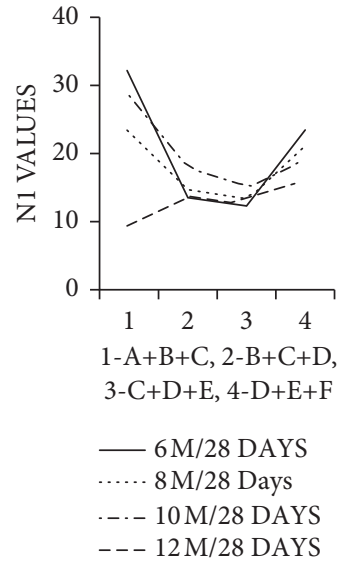

Figure 9: N1 values with increasing composition (28 days' curing) combinations from A to F.

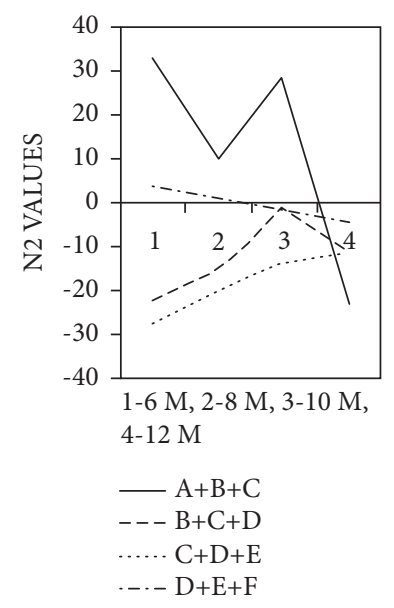

FIGURE 10: N2 values with increasing molarity of alkaline solution (28 days' curing).

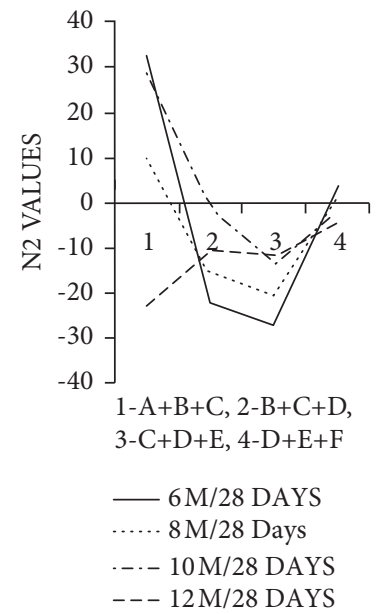

FIgURE 11: N2 values with increasing composition combinations from A to F (28 days' curing). 


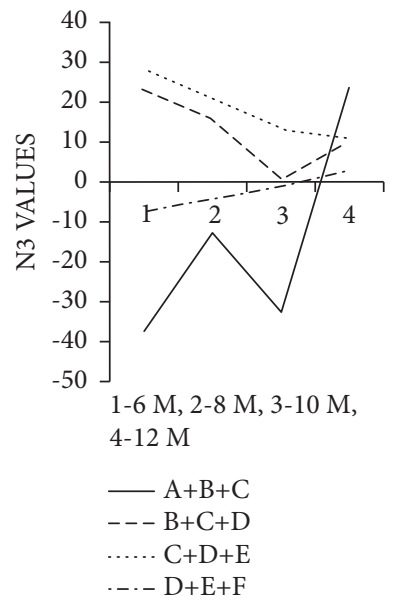

FIGURE 12: N3 values with increasing molarity alkaline solution (28 days' curing) combinations.

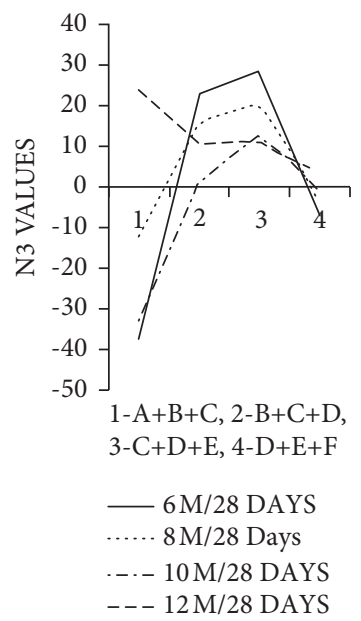

Figure 13: N3 values with increasing composition from A to F (28 days' curing).

TABle 5: Trend of silica, alumina, and calcia moles and the ratios of $\mathrm{Al} / \mathrm{Si}, \mathrm{Ca} / \mathrm{Si}$, and $\mathrm{Ca} /(\mathrm{Si}+\mathrm{Al})$.

\begin{tabular}{lcccccc}
\hline Combinations & $\mathrm{SiO} 2 \mathrm{~mol}$ & $\mathrm{Al} 2 \mathrm{O} 3 \mathrm{~mol}$ & $\mathrm{CaO} \mathrm{mol}$ & $\mathrm{Al} / \mathrm{Si}$ & $\mathrm{Ca} / \mathrm{Si}$ & $\mathrm{Ca} /(\mathrm{Si}+\mathrm{Al})$ \\
\hline $\mathrm{A}+\mathrm{B}+\mathrm{C}(1)$ & 0.87 & 0.24 & 0.22 & 0.28 & 0.25 & 0.20 \\
$\mathrm{~B}+\mathrm{C}+\mathrm{D}(2)$ & 0.83 & 0.23 & 0.27 & 0.28 & 0.33 & 0.25 \\
$\mathrm{C}+\mathrm{D}+\mathrm{E}(3)$ & 0.78 & 0.23 & 0.33 & 0.29 & 0.42 & 0.32 \\
$\mathrm{D}+\mathrm{E}+\mathrm{F}(4)$ & 0.74 & 0.22 & 0.38 & 0.30 & 0.51 & 0.40 \\
\hline
\end{tabular}

\section{Conclusions}

The proposed empirical model of the geopolymer reactions has drawn out the following conclusions:

(1) Depending on overall silica, alumina, and calcia ratios in the mix compositions, the compressive strength changed and this aspect was found to be dependent on overall $\mathrm{Al} / \mathrm{Si}, \mathrm{Ca} / \mathrm{Si}$, and $\mathrm{Ca} /(\mathrm{Si}+\mathrm{Al})$ ratios.

(2) The mix compositions (B and C) showed positive trend with regard to the compressive strength, for both 7 days' and 28 days' curing. 
(3) An interdependence between $\mathrm{Ca} / \mathrm{Si}$ ratio and $\mathrm{Ca} /$ $(\mathrm{Si}+\mathrm{Al})$ ratios is found to exist. A fall in the strength due to $\mathrm{Ca} / \mathrm{Si}$ ratio catalyzes the role of $\mathrm{Ca} /(\mathrm{Si}+\mathrm{Al})$ to become more effective towards strength development of tested bricks.

(4) The method proposed in the study, involving the combination of correlation coefficient and linear regression analysis, is considered useful to empirically capture the complex nature of geopolymerization.

\section{Data Availability}

The data used to support the findings of this study are included within the article, and further data or information required is available from the corresponding author upon request.

\section{Conflicts of Interest}

The authors declare that they have no conflicts of interest.

\section{References}

[1] C. Shi and J. Qian, "High performance cementing materials from industrial slags - a review," Resources, Conservation and Recycling, vol. 29, no. 3, pp. 195-207, 2000.

[2] C. Li, H. Sun, and L. Li, "A review: The comparison between alkali-activated slag $(\mathrm{Si}+\mathrm{Ca})$ and metakaolin $(\mathrm{Si}+\mathrm{Al})$ cements," Cement and Concrete Research, vol. 40, no. 9, pp. 1341-1349, 2010.

[3] C. L. Nicholson, B. J. Murray, R. A. Fletcher, D. Brew, K. J. D. Mackenzie, and M. Schmücker, Novel Geopolymer Materials Containing Borate Structural Units, Vol. 31-33, World Congress Geopolymer, , (Saint-Quentin), 2005.

[4] J. Tailby and K. J. D. MacKenzie, "Structure and mechanical properties of aluminosilicate geopolymer composites with Portland cement and its constituent minerals," Cement and Concrete Research, vol. 40, no. 5, pp. 787-794, 2010.

[5] V. Benavent, P. Steins, I. Sobrados, J. Sanz, D. Lambertin, and F. Frizon, "Impact of aluminium on the structure of geopolymers from the early stages to consolidated material," Cement and Concrete Research, vol. 90, pp. 27-35, 2016.

[6] S. Alonso and A. Palomo, "Alkaline activation of metakaolin and calcium hydroxide mixtures: influence of temperature, activator concentration and solids ratio," Materials Letters, vol. 47, pp. 55-62, 2001.

[7] P. Suraneni, S. Puligilla, E. H. Kim, X. Chen, L. J. Struble, and P. Mondal, "Monitoring setting of geopolymers," Adv Civil Eng Mater, vol. 3, pp. 177-192, 2014.

[8] W. K. W. Lee and J. S. J. van Deventer, "The effect of ionic contaminants on the early-age properties of alkali-activated fly ash-based cements," Cement and Concrete Research, vol. 32, pp. 577-584, 2002.

[9] C. K. Yip and J. S. J. van Deventer, "Microanalysis of calcium silicate hydrate gel formed within a geo-polymeric binder," Journal of Materials Science, vol. 38, no. 18, pp. 3851-3860, 2003.

[10] X. Chen, A. Sutrisno, and L. Struble, "Effects of calcium on setting of metakaolin based geopolymer," Journal of the American Ceramic Society, vol. 101, pp. 957-968, 2018.
[11] S. Pulgalia and P. Mondal, "Co-existence of aluminosilicate and calcium silicate gel characterized through selective dissolution and FTR spectral subtraction," Cement and Concrete Research, vol. 70, pp. 39-49, 2015.

[12] D. V. Dao, S. H. Trinh, H. B. Ly, and B. T. Pham, "Prediction of compressive strength of geopolymer concrete using entirely steel slag aggregates: novel hybrid artificial intelligence approaches," Applied Sciences, vol. 9, no. 6, p. 1113, 2019.

[13] M. M. Yadollahi, A. Benli, and R. Demirboğa, "Prediction of compressive strength of geopolymer composites using an artificial neural network," Materials Research Innovations, vol. 19, no. 6, pp. 453-458, 2015.

[14] F. Naseri, F. Jafari, E. Mohseni, W. Tang, A. Feizbakhsh, and M. Khatibinia, "Experimental observations and SVM-based prediction of properties of polypropylene fibres reinforced self-compacting composites incorporating nano- $\mathrm{CuO}$," Construction and Building Materials, vol. 143, pp. 589-598, 2017.

[15] M. M. Khotbehsara, B. M. Miyandehi, F. Naseri, T. Ozbakkaloglu, F. Jafari, and E. Mohseni, "Effect of SnO2, $\mathrm{ZrO} 2$, and $\mathrm{CaCO} 3$ nano particles on water transport and durability properties of self-compacting mortar containing fly ash: experimental observations and ANFIS predictions," Construction and Building Materials, vol. 158, pp. 823-834, 2018.

[16] B. Badarloo, A. Kari, and F. Jafari, "Experimental and numerical study to determine the relationship between tensile strength and compressive strength of concrete," Civil Engineering Journal, vol. 4, no. 11, pp. 2787-2800, 2018.

[17] P. O. Awoyera, M. S. Kirgiz, A. Q. Viloria, and D. OvallosGazabon, "Estimating strength properties of geopolymer selfcompacting concrete using machine learning techniques," Journal of Materials Research and Technology, vol. 9, no. 4, pp. 9016-9028, 2020.

[18] M. Zhang, N. A. Deskins, G. Zhang, and R. T. Cygan, "Modeling the polymerization process for geopolymer synthesis through reactive molecular dynamics simulations," Physical Chemistry C.vol. 122, no. 12, pp. 6760-6773, 2018.

[19] Y. F. Cui, K. K. Gao, and P. Zhang, "Experimental and statistical study on mechanical characteristics of geopolymer concrete," Materials, vol. 13, no. 7, p. 1651, 2020.

[20] Y. F. Ling, Proportion and Performance Evaluation of Fly AshBased Geopolymer and its Application in Engineered Composites, PhD Dissertation, Iowa State University, Lowa, USA, 2019.

[21] A. Siva Krishna and V. Ranga Rao, "Strength prediction of geopolymer concrete using ANN," International Journal of Recent Technology and Engineering (IJRTE), vol. 7, no. 6C2, pp. 661-667, 2019.

[22] H. Mehdizadeh, E. N. Kani, M. Hamideh, and E. N. Kani, "Modelling the influence of chemical composition on compressive strength behavior of alkali-activated phosphorus slag cement using statistical design," Canadian Journal of Civil Engineering, vol. 45, no. 12, pp. 1073-1083, 2018. 